\title{
Evaluation of original historical clones of hops (Humulus lupulus L.)
}

\author{
Vladimír Nesvadba*, Jitka Charvátová, Alena Henychová, Josef Patzak
}

Hop Research Institute Co., Ltd., Kadanská 2525, 43801 Žatec,

Czech Republic

*corresponding author: nesvadba@chizatec.cz

\begin{abstract}
The aim of this study was to compare yield and technological parameters of Czech historical hop clones, which were grown in our current climatic conditions. The highest yields from the selected original hop clones were found in "Úštěcký smetaňák" (1.93 t/ha), "Dubský zeleňák" (1.80 t/ha) and "Hřebčí chmel" (1.51 t/ha), which is probably caused by a genetic difference from Saazer hop. On the contrary, a low yield of hops was recorded in "Mastýřvický" ( $0.50 \mathrm{t} / \mathrm{ha})$. In terms of brewing parameters, the highest contents of valuable alpha acids were detected in Osvald's clones no. $147 \mathrm{a} / \mathrm{I}(3.88 \% \mathrm{w} / \mathrm{w})$, no. $86(3.71 \% \mathrm{w} / \mathrm{w})$ together with no. $114(3.45 \% \mathrm{w} / \mathrm{w})$, while the lowest level $(1.05 \% \mathrm{w} / \mathrm{w})$ was found in "Hřebčí chmel" and "Úštěcký smetaňák". The highest contents of essential oils were measured in Osvald's clone no. 147 a/I (0.77\% w/w), "Žatecká populace" (0.68\% w/w) and Osvald's clone no. $126(0.65 \%$ w/w). Vice versa, the clones "Masty̌řovický" ( $0.35 \%$ w/w), "Hřebčí chmel" (0.35\% w/w) and "Trš̌ický" ( $0.31 \%$ w/w.) exhibited the lowest contents. The evaluated hops displayed a relatively balanced composition of essential oils with the exception of "Dubský zeleňák", which has an extremely low ratio of farnesene ( $4.35 \%$ rel.), but also a high ratio of selinene (8.95\% rel.). Osvald's clone no. $124 \mathrm{~b}$ and 126 is genetically identical with the variety of Fuggle. The results show that clones "Hřebčí chmel", "Úštěcký smetaňák" and "Dubský zeleňák" are different from other clones.
\end{abstract}

Key words: hops, Humulus lupulus L., yield, hop resin, essential oils

\section{Introduction}

Foundations of hop breeding were laid on a simple selection from populations of wild hops that were first used for beer brewing. Based upon the beer quality, the best wild hops were gradually selected in individual areas.

The locations, where these hop varieties grew, were inherited from one generation to another and hops were gradually introduced in gardens and later planted in hop yards. This resulted in a higher production of beer, first in monasteries and later in breweries. These hops were used for propagation. In this way original regional hop varieties in the Czech lands (žatecký, úštěcký, dubský, hřebčí, etc.) emerged. It was the quality of beer which proved that the best hops for beer brewing came from the
Žatec (Saaz) hop growing region. Most documents on the importance of Czech hops date back to the reign of Emperor Charles IV. who banned export of Žatec (Saaz) hop cuttings abroad (Nesvadba, 2008).

Czech hops became famous worldwide thanks to excellent work of experts and breeders. The first clonal selection was performed by Kryštof Semš from Vrbice near Roudnice in his hop garden (Úštěk hop growing region).

Later Göpp (1942) described how this hop was obtained: "In 1853 and 1854 Semš grew hop on hop poles. When he was observing his plants, he found out that one of the plants was much more vigorous with more cones and the beginning of its inflorescence was earlier. Its cones 
were compact and dense with few leaves only. This plant was therefore used as a mother one and within a short time it became famous as Semšs hop". Göpp also stated that Semš had managed to find a real mutation, which showed better characteristics in comparison with other plants. Later it became the first Czech hop variety known as mentioned above, Semšs hop. Approximately at that time the business name "red bine hop" emerged in several versions: "Starožatecký" (English meaning “Old Saazer”), „Staroúštěcký“ ("Old Úštěk”) and „Český“ ("Czech"). At the turn of the $19^{\text {th }}$ and $20^{\text {th }}$ century the name "Starožatecký" ("Old Saazer") prevailed.

This trend was typical also for the Úštek hop growing region. Chodounský (1900) indicated that in February 190032 villages in the Polepy region agreed that no one of the growers would sell more planting material and significantly fewer growers from this area had preferred hops from the Žatec (Saaz) hop growing region. Thus, Lučan and Blato were the first hop varieties to be grown. Lučan originated from maintained and improved breeding variety of "Žatecký krajový" ("Saazer region") and was registered in 1941. Blato was registered in 1952 and it arised from the regional variety of "Úštěcký krajový." ("Úštěk region").

The founder of modern hop breeding methods, that utilised clonal selection from original regional plants, was Dr. Karel Osvald. He had worked on clonal selection since 1927 when he selected 150 clones and subsequently he planted two cuttings from each (Osvald, 1929; 1931). Some of these clones are still kept in a field collection of genetic resources, including the original regional hops (Dubský zeleňák, Mastýřovický, Hřebčí chmel, Úštěcký smetaňák etc.). Thanks to Dr. Osvald we have three clones, which were also named after him. He selected his clone no. 114 for further growing. The clones were recognized in 1946 and due to their significantly better quantitative as well as qualitative features, they were approved for growing in 1952. At present, they are grown at $90 \%$ of hop growing area in CR.

Breeding efforts led to a registration of other clones such as e.g. Siřem (1969), Zlatan (1976), Podlešák (1989) and Blšanka (1993). These clones were described by Beránek (1970), Zelenka and Rígr (1983), Slabyhoudek (1985), Rígr and Beránek (1991), Linhart and Nesvadba (1994). Unfortunately, they are not grown any more.

Considerable differences in the course of weather conditions have been occurring in recent years. Some years are dry or with high temperatures which has a significant impact on qualitative and quantitative parameters of hop (Krofta et al., 2019; Krofta et al., 2020). For this reason we have decided to test also other original hop clones, which originate in Žatec (Saaz) hops. Osvald bred them one hundred years ago, and nowadays these clones can present attractive raw material for beer brewing in the light of changing climatic conditions. Therefore, we have selected the best genotypes from our field collection, which were evaluated subsequently.

\section{Material and methods}

\section{Plant material and weather conditions}

The evaluation was carried out in 2018 and 2019 within the Czech Republic's collection of genetic resources, which is kept on the farm of the Hop Research Institute in Stekník near Žatec (Saaz). Agro-technical operations, fertilization and protection against pests and diseases were made conducted in accordance with the methodology (Ježek et al., 2015). The clones that were selected for this study are listed in Table 1.

Table 1 The hop clones used in this study selected from the Czech Republic's collection of genetic resources

\begin{tabular}{|l|c|}
\hline \multicolumn{1}{|c|}{ Selected hop clones ${ }^{\text {a) }}$} & Designation $^{\text {b) }}$ \\
\hline Osvald's clone no. 31 & 31 \\
\hline Osvald's clone no. 72 & 72 \\
\hline Osvald's clone no. 86 & 86 \\
\hline Osvald's clone no. 114 & 114 \\
\hline Osvald's clone no. 124b & $124 \mathrm{~b}$ \\
\hline Osvald's clone no. 126 & 126 \\
\hline Osvald's clone no. 136b & $136 \mathrm{~b}$ \\
\hline Osvald's clone no. 147 a/l & 147 a/I \\
\hline Mastýřovický & $\mathrm{M}$ \\
\hline Staročeský & $\mathrm{S}$ \\
\hline Tršický & $\mathrm{T}$ \\
\hline Žatecká populace & $\mathrm{ZP}$ \\
\hline Hřebčí chmel & $\mathrm{HCH}$ \\
\hline Úštěcký smetaňák & $\mathrm{US}$ \\
\hline Dubský zeleňák & $\mathrm{DZ}$ \\
\hline
\end{tabular}

a) Official (registered) name of the clones.

${ }^{b)}$ Designations introduced only in this paper to simplify the text.

The growing conditions for the assessed genotypes are as follows: the hop garden is situated at $215 \mathrm{~m}$ above sea level in the Žatec (Saaz) hop growing region, in the sub-region "Střední Poohří", which is characterised by warm and dry weather conditions. The sum of temperatures $>10^{\circ} \mathrm{C}$ amounts to $2,600-2,800{ }^{\circ} \mathrm{C}$ per year.

The course of the average monthly temperatures in 2018 and 2019 compared to the last thirty-year average (Czech Hydro-meteorological Institute) at the locality of 
Stekník is obvious from Figure 1. In 2018, the temperatures were higher than the thirty-year average with the exception of February and March. The year 2019 was also warmer, with the only exception of May.

Figure 1 Average monthly temperatures in 2018 and 2019 (Research farm in Stekník)

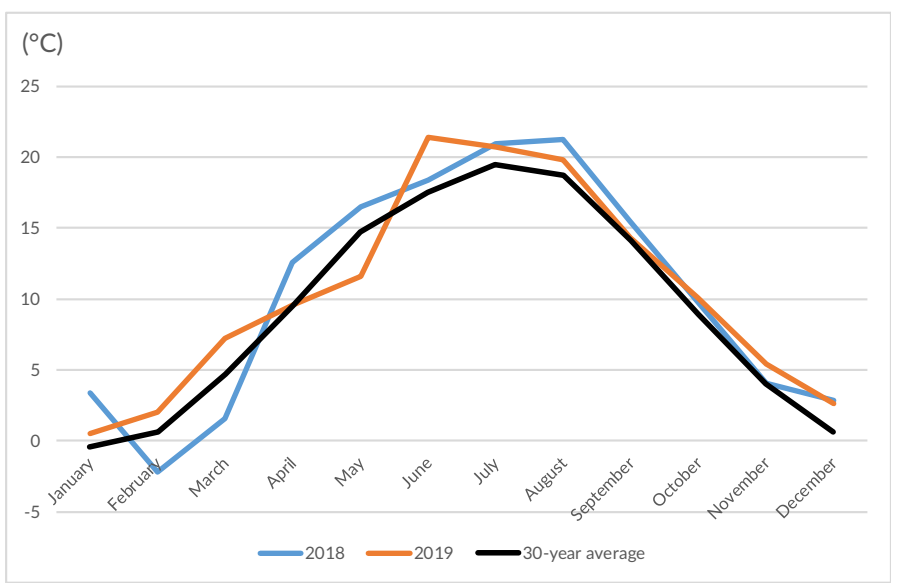

Each plant was harvested individually using a Wolf pilot stationary picking machine. The yield is given in tons per hectare (t/ha). Just after the harvest, the yield was expressed in kilograms of raw hops per plant. The conversion results are based on the number of plants per hectare. Under the spacing $1.14 \times 3.0 \mathrm{~m}$ it represents 3,300 plants/ha. The coefficient of dry matter in raw hops to dry hops amounts to 4 .

The content and composition of hop resins and essential oils were determined using liquid chromatography according to EBC 7.7 (Krofta, 2008). DNA was isolated from young leaves of plants by CTAB method and molecular analyses of 16 microsatellite loci were carried out according to Patzak et al. (2017). Eighteen world old landrace cultivars and twenty-one Czech hop cultivars were used for comparison in genetic diversity study. Dendrogram was based on Jaccard's similarity coefficient of 152 EST-SSR polymorphic molecular markers, determined by Neigh-
Figure 2 demonstrates the sum of precipitations in the Sketník region in 2018 and 2019 supplemented with the thirty-year average. The period from January to August presents key months for growing of hop. Rainfall in September already has no effect on the qualitative and quantitative parameters of hop as harvest takes place in the third decade of August.

Thus, the figure 2 shows that in January 2018 the sum of precipitations was higher than the thirty-year average, whereas in 2019 it was only a half below that level. In February and April of 2018, the rainfall was significantly low, on the contrary in March it was noticeably higher. In 2019 the total precipitations between February and April were approaching the thirty-year average. And also the precipitations in May and June of 2018 as well as of 2019 were comparable with the average of the last 30 years. Nevertheless, the rainfalls in further months of July and August in both monitored years were substantially lower. Especially the months in 2018 can be described as very poor in precipitations (the mere $17.4 \mathrm{~mm}$ in July and $20.0 \mathrm{~mm}$ in August).

\section{Soil characteristics, harvest, analyses and statistics}

Pedological characteristics describe the soil as light alluvial with colluvial and alluvial sediments. It is a plain without symptoms of surface water erosion. The exposition is omnidirectional without skeleton and deep more than $60 \mathrm{~cm}$.
Figure 2 Month sums of precipitations in 2018 and 2019 (Research farm in Stekník)

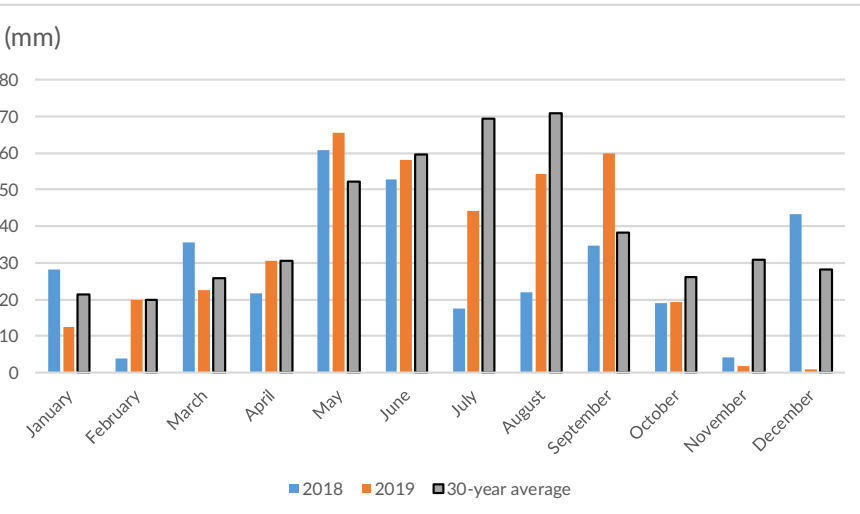

bor-Joining (NJ) method of Unweighted Pair Group Method with Arithmetic means (UPGMA) in DARwin v. 5.0.155 (Dissimilarity Analysis and Representation for Windows, http://darwin.cirad.fr/darwin) software, visualized by Geneious Pro 4.8.2 (Biomatters Ltd., Auckland, New Zealand) software.

Basic statistical methods were used for assessment of chemical analyses within the whole set of hop clones: medium, standard deviation and variability expressed in percentage (hundredfold of variance coefficient). Parameters " $x-s$ ", " $x+s$ ", " $x-2 s$ " and " $x+2 s$ " point to a difference of an individual clone within the set. If a clone exceeds the level " $\mathrm{x} \pm \mathrm{s}$ ", it is different from the medium of the individuals. If it exceeds the level of " $x \pm 2 s$ ", it goes beyond the 
given set. These limit levels within a set are commonly used in hop breeding. If a variability is too wide, limit level of " $x \pm 3 s$ " can be used (Nesvadba, 2001).

\section{Results and discussion}

\section{Yield of hops during harvest}

The average yield in all clones was $0.96 \mathrm{t} / \mathrm{ha}$ under the variability of $45.47 \%$. Figure 3 provides an overview of the yields of the individual hop clones, whose parameters were evaluated in this study. Figure 3 reveals that the clones US (1.93 t/ha), DZ (1.80 t/ha) and HCH (1.51 t/ha) achieved the highest yield. According to the Catalogue of Czech hop varieties (Nesvadba et al., 2012), the values of US and DZ reached the low yield level of commercial varieties Sládek, Harmonie, Bor, Premiant, Rubín, Agnus and Vital (1.8 t/ha). The level of " $x+2 s$ " (1.84 t/ha) was exceeded only by the clone US and the level of „, $\mathrm{x}+\mathrm{s}^{\prime \prime}$ (1.40 t/ha) by the clones DZ and HCH. On the contrary, the clone $\mathrm{M}(0.50 \mathrm{t} / \mathrm{ha})$ was under the level of " $x$-s" ( $0.53 \mathrm{t} / \mathrm{ha})$. The average yield was recorded also in Osvald's clones no. 31 (0.58 t/ha), 72 (0.64 t/ha) and 114 (0.90 t/ha), and a higher yield of $1.10 \mathrm{t} / \mathrm{ha}$ was detected in Osvald's clone no. 136b. Merely Osvald's clone no. 114 fulfilled the yield range mentioned in the Catalogue of Czech hop varieties (0.8-1.5 t/ha) (Nesvadba et al., 2012). Nevertheless, this value concerns hop plants, which have their origin in virus free planting material, while the tested clones were not virus-free. This is the reason why there was a lower yield level than in conventional hop gardens planted from virus-free material.

Figure 3 An overview of the yield of monitored hops

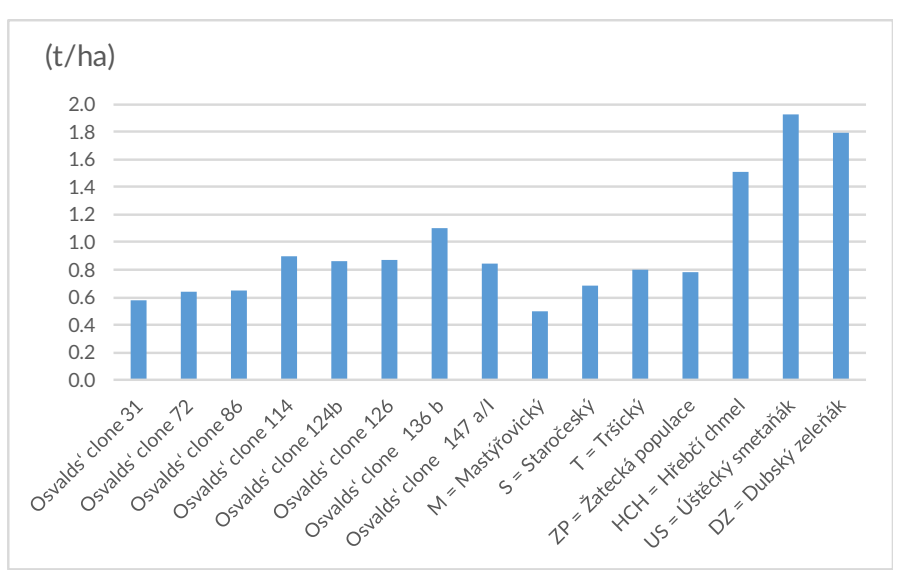

$2.59 \% \mathrm{w} / \mathrm{w}$, under the variability of $33.06 \%$. Osvald's clones no. 147 a/I $(3.88 \% \mathrm{w} / \mathrm{w})$, no. $86(3.71 \% \mathrm{w} / \mathrm{w})$ and no. $114(3.45 \% \mathrm{w} / \mathrm{w})$ reached the values above the level " $x+s$ " $(3.44 \% \mathrm{w} / \mathrm{w})$. This content of alpha acids corresponded only to the variety of Saazer (Nesvadba et al., 2013). If we take into account yields from conventional hop gardens, Saaz Late achieved also a higher content of alpha acids (3.0\% w/w) (Krofta et al., 2020). On the contrary, clones with alpha acid content at the level of $1.05 \%$ w/w (i.e. HCH and US) were under the level of " $x$-s".

\section{Beta acids}

The average content of beta acids was $3.76 \% \mathrm{w} / \mathrm{w}$, under the variability of $19.71 \%$. Further we compared the variability in the content of beta and alpha acids and found of $13.35 \%$ lower variability in alpha acids content. This indicated that the content of beta acids in the tested hop clones was more stable than the content of alpha acids. As for the content of beta acids, Osvald's clones no. $124 \mathrm{~b}(2.21 \% \mathrm{w} / \mathrm{w})$ and $126(2.81 \% \mathrm{w} / \mathrm{w})$ as well as $\mathrm{S}(2.61 \% \mathrm{w} / \mathrm{w})$ were under the level of "x-s" $(3.02 \% \mathrm{w} / \mathrm{w})$.

\section{The ratio of alpha/beta acids}

The ratio of alpha/beta acid of 1.0 is typical for the variety of Saazer. Our results thus revealed that the evaluated set of clones had a low ratio of alpha/beta $(0.73 \%)$ under a high variability (36.59\%). The level of " $\mathrm{x}+\mathrm{s}$ " (1.0) was exceeded by the clones with a low ratio of beta acids, i.e. no. 126 (alpha/beta ratio was 1.06) and no. 124b (alpha/beta ratio was 1.12). On the other hand, clones with a lower content of alpha acids, i.e. HCH (alpha/beta ratio was 0.27), US (alpha/beta ratio was 0.25 ) and Osvald's clone no. 136b (alpha/beta ratio was 0.41 ) were under the level of " $\mathrm{x}$-s" (0.46). Only the variety of Mimosa had such a low ratio of alpha/beta acids (Nesvadba et al., 2020).

\section{Cohumululone}

The average ratio of cohumulone $24.05 \%$ rel. was determined under the variability of $7.52 \%$. A low variability showed that the ratio of cohumulone in the tested clones was stable. Osvald's clones no. 124b (28.35\%) and no. 126 (25.90\% rel.) reached the ratio of cohumulone above the level of " $x+s$ " (25.86\% rel.). Osvald's clone no. $124 \mathrm{~b}$ had the ratio of cohumulone even higher than $26 \%$ rel., which was the maximum value

\section{Alpha acids}

Average values of the content and composition of essential oils, including basic statistical assessment, are shown in Table 2. The average content of alpha acids within the whole set of tested clones amounted to of Saazer ratio (Nesvadba et al., 2013). Vice versa, clones $\mathrm{T}(22.10 \%$ rel.) and DZ (20.50\% rel.) fell under the level "x-s" (22.24\% rel.). A low ratio of cohumulone is typical for Harmonie and Premiant as well. The average ratio of cohumulone was $39.69 \%$ under a very low variability (5.99\%). 


\section{Colupulone}

The highest ratio of colupulone was found in Osvald's clones no. $124 \mathrm{~b}$ (45.85\% rel.) and 126 (43.20\% rel.) together with the clone S ( $42.55 \%$ rel.). It is worth noting that no genotype displayed the ratio of colupulone under the level of "x-s" (37.32\% rel.).

\section{Xanthohumole}

The average content of xanthohumole $(0.24 \% \mathrm{w} / \mathrm{w})$ was very low. Agnus and Vital with the level of $1.0 \% \mathrm{w} / \mathrm{w}$ showed the highest contents of xanthohumole from all Czech varieties (Nesvadba and Krofta, 2008). The content of xanthohumole above the level of " $\mathrm{x}+\mathrm{s}$ " $(0.31 \% \mathrm{w} / \mathrm{w})$ was recorded in Osvald's clones no. $86(0.34 \% \mathrm{w} / \mathrm{w})$, $31(0.33 \% \mathrm{w} / \mathrm{w}), 72(0.32 \% \mathrm{w} / \mathrm{w})$ and no. $147 \mathrm{a} / \mathrm{I}$ $(0.32 \% \mathrm{w} / \mathrm{w})$. Out of all the cultivated Czech varieties such a low content of xanthohumole was detected only in Saazer, Saaz Late, Kazbek and Premiant. Only HCH $(0.15 \%$ w/w), US $(0.16 \% \mathrm{w} / \mathrm{w})$ and DZ $(0.17 \% \mathrm{w} / \mathrm{w})$ got under the level of " $\mathrm{x}$-s" $(0.18 \% \mathrm{w} / \mathrm{w})$ in the content of xanthohumole. At the same time, we would like to remind that these three clones exhibited the highest yield during harvest.
Brewers carry out hopping according to the content of alpha acids. The highest ratio of xanthohumole/alpha (14.83) was found in US. This clone together with the clone HCH (14.35) exceeded the level of " $x+2 s$ " (14.04). We noticed that no clone had the ratio of xanthohumole/ alpha lower than 7.78.

\section{Desmethylxanthohumol (DMX)}

The average content of DMX amounted to $0.05 \% \mathrm{w} / \mathrm{w}$ under the variability of $30.72 \%$. The highest amount was determined in DZ $(0.08 \% \mathrm{w} / \mathrm{w})$, which was the only one to exceed the level of " $\mathrm{x}+2 \mathrm{~s}$ " $(0.08 \% \mathrm{w} / \mathrm{w})$.

The content of DMX higher than $0.08 \% \mathrm{w} / \mathrm{w}$ was detected in a few varieties, i.e. Bor, Agnus and Vital (Nesvadba et al., 2013). Still, this is not a significant content of DMX because Vital showed up to a five times higher level of DMX (Krofta et al., 2013). The level of " $x+s$ " $(0.06 \% \mathrm{w} / \mathrm{w})$ was exceeded in Osvald's clone no. 136b. As for the content of DMX, Osvald's clone no. $124 \mathrm{~b}$ $(0.03 \% \mathrm{w} / \mathrm{w}), \mathrm{HCH}(0.03 \% \mathrm{w} / \mathrm{w})$ and US $(0.03 \% \mathrm{w} / \mathrm{w})$ ranged at the level of " $\mathrm{x}-\mathrm{s}$ " $(0.03 \% \mathrm{w} / \mathrm{w})$.

Table 2 The composition of hop resins and polyphenols and their content in studied hop clones

\begin{tabular}{|c|c|c|c|c|c|c|c|c|}
\hline Clone & $\begin{array}{l}\text { Alpha acids } \\
(\% \mathrm{w} / \mathrm{w})\end{array}$ & $\begin{array}{l}\text { Beta acids } \\
(\% \mathrm{w} / \mathrm{w})\end{array}$ & $\begin{array}{c}\text { Ratio } \\
\text { alpha/beta }\end{array}$ & $\begin{array}{l}\text { Cohumulone } \\
\text { (\% rel.) }\end{array}$ & $\begin{array}{l}\text { Colupulone } \\
\text { (\% rel.) }\end{array}$ & $\begin{array}{l}\text { Xanthohumole } \\
(\% \mathrm{w} / \mathrm{w})\end{array}$ & $\begin{array}{c}\text { Ratio } \\
\text { xanth./alpha }\end{array}$ & $\begin{array}{l}\text { DMX* }^{*} \\
(\% \mathrm{w} / \mathrm{w})\end{array}$ \\
\hline Osvalds' clone 31 & 3.36 & 4.41 & 0.78 & 24.45 & 38.40 & 0.33 & 9.82 & 0.05 \\
\hline Osvalds' clone 72 & 2.99 & 3.57 & 0.86 & 24.25 & 40.10 & 0.32 & 10.55 & 0.05 \\
\hline Osvalds' clone 86 & 3.71 & 4.43 & 0.85 & 23.35 & 39.20 & 0.34 & 9.04 & 0.05 \\
\hline Osvalds' clone 114 & 3.45 & 3.85 & 0.94 & 23.35 & 38.35 & 0.30 & 8.85 & 0.05 \\
\hline Osvalds' clone 124b & 2.53 & 2.21 & 1.12 & 28.35 & 45.85 & 0.22 & 8.50 & 0.03 \\
\hline Osvalds' clone 126 & 2.75 & 2.81 & 1.06 & 25.90 & 43.20 & 0.24 & 8.55 & 0.04 \\
\hline Osvalds' clone $136 \mathrm{~b}$ & 1.96 & 4.73 & 0.41 & 22.30 & 37.55 & 0.20 & 9.95 & 0.08 \\
\hline Osvalds' clone $147 \mathrm{a} / \mathrm{I}$ & 3.88 & 4.58 & 0.86 & 23.20 & 38.95 & 0.32 & 8.13 & 0.06 \\
\hline$M=$ Mastýřovický & 2.44 & 3.61 & 0.68 & 24.70 & 40.00 & 0.26 & 10.68 & 0.05 \\
\hline $\mathrm{S}=$ Staročeský & 2.34 & 2.61 & 0.94 & 25.45 & 42.55 & 0.20 & 8.35 & 0.04 \\
\hline T = Tršický & 2.20 & 3.46 & 0.64 & 22.10 & 38.45 & 0.20 & 8.86 & 0.05 \\
\hline ZP = Žatecká populace & 3.01 & 3.92 & 0.78 & 24.25 & 38.20 & 0.29 & 9.47 & 0.06 \\
\hline $\mathrm{HCH}=$ Hřebčí chmel & 1.05 & 3.94 & 0.27 & 24.30 & 37.85 & 0.15 & 14.35 & 0.03 \\
\hline US = Úštěcký smetaňák & 1.05 & 4.02 & 0.25 & 24.30 & 39.10 & 0.16 & 14.83 & 0.03 \\
\hline DZ = Dubský zeleňák & 2.11 & 4.30 & 0.52 & 20.50 & 37.65 & 0.17 & 8.08 & 0.08 \\
\hline$x$ & 2.59 & 3.76 & 0.73 & 24.05 & 39.69 & 0.24 & 9.87 & 0.05 \\
\hline s & 0.85 & 0.74 & 0.27 & 1.81 & 2.38 & 0.07 & 2.09 & 0.02 \\
\hline Vk & 33.06 & 19.71 & 36.59 & 7.52 & 5.99 & 27.26 & 21.14 & 30.72 \\
\hline$x-s$ & 1.73 & 3.02 & 0.46 & 22.24 & 37.32 & 0.18 & 7.78 & 0.03 \\
\hline$x+s$ & 3.44 & 4.50 & 1.00 & 25.86 & 42.07 & 0.31 & 11.95 & 0.06 \\
\hline$x-2 s$ & 0.88 & 2.28 & 0.20 & 20.43 & 34.94 & 0.11 & 5.69 & 0.02 \\
\hline$s+2 s$ & 4.30 & 5.25 & 1.27 & 27.67 & 44.45 & 0.38 & 14.04 & 0.08 \\
\hline
\end{tabular}

*desmethylxanthohumol 


\section{Essential oils}

From Table 2 it is obvious that the average content of essential oils in the tested clones is $0.50 \%$ under the variability of $27.04 \%$. The content of essential oils under the level of "x-s" $(0.37 \% \mathrm{w} / \mathrm{w})$ were found in the clones $\mathrm{M}(0.35 \% \mathrm{w} / \mathrm{w}), \mathrm{HCH}(0.35 \% \mathrm{w} / \mathrm{w})$ and T $(0.31 \% \mathrm{w} / \mathrm{w})$. Osvald's clones no.147 a/I $(0.77 \% \mathrm{w} / \mathrm{w})$ and 126 $(0.65 \% \mathrm{w} / \mathrm{w})$ together with ZP $(0.68 \% \mathrm{w} / \mathrm{w})$ were above the level of „X+s“ $(0.64 \% \mathrm{w} / \mathrm{w})$. A similar content of essential oils was measured only in Saazer and Saaz Late, whose content lies between 0.4 and $0.8 \% \mathrm{w} / \mathrm{w}$, resp. between 0.5 and $1.0 \%$ w/w (Nesvadba et al., 2013). Compositions of essential oils can be compared with the Catalogue of Czech hop varieties (Nesvadba, 2012).

\section{Myrcene}

The average ratio of myrcene amounted to $16.10 \%$ rel. under $20.70 \%$ variability. The ratio of myrcene under the level of " $\mathrm{x}-\mathrm{s}$ " (12.77\% rel.) was found in $\mathrm{T}$ (10.53\% rel.) and Osvald's clone no. 136b (11.75\% rel.). The clone M (20.03\% rel.) and Osvald's clone no. 31 (20.01\% rel.) were above the " $\mathrm{x}+\mathrm{s}$ " level. An extremely high ratio of myrcene reached Osvald's clone no. 147 a/I (23.41\% rel.), which exceeded the level of " $x+2 s$ " (22.76\% rel.). The ratio of myrcene in all clones was at a low level, similarly as in Saazer and Saaz Late.

\section{Caryophyllene}

The average ratio of caryophyllene amounted to $11.19 \%$ rel. under $20.94 \%$ variability. It is worth noting that under the level of " $\mathrm{x}-\mathrm{s}$ " (8.85\% rel.) there were Osvald's clones no. 31 (7.99\% rel.) and 72 (8.76\% rel.). The ratio of caryophyllene above the level of " $x+s$ " (13.54\% rel.) was measured in DZ (15.85\% rel.), Osvald's clones no. $124 \mathrm{~b}$ (14.73\% rel.) and 126 (14.32\% rel.). These clones with a higher amount of caryophyllene exhibited a ratio comparable with the Czech varieties characterized by a higher level of this compound, i.e. of up to 15\% rel. (Bor, Kazbek, Agnus).

\section{Farnesene}

The clone S (23.81\% rel.) together with Osvald's clone no. $114(21.40 \%)$ got above the level of " $x+s$ " (21.34\% rel.) in terms of the ratio of farnesene. Only Osvald's clones no. $124 \mathrm{~b}$ and 126 had a lower ratio of farnesene than Saazer and Saaz Late. An extremely low ratio of farnesene, under the level of "x-2s" (7.10\% rel.) was detected in DZ (4.35\% rel.). Saaz hops are characterized by a higher ratio of farnesene, which was found in all the clones except DZ. The same ratio of farnesene as DZ was discovered also in Bohemie, Vital and the new variety of Gaia.

\section{Humulene}

The average ratio of humulene amounted to $24.65 \%$ rel. under $15.27 \%$ rel. variability, which was the lowest value within all the detected essential oils. The ratio of humulene above the level of " $\mathrm{x}$-s" (20.88\% rel.) was found in Osvald's clone no. 147 a/I (17.89\% rel.). On the contrary, Osvald's clones no. 124b (32.13\% rel.), 136b ( $28.60 \%$ rel.) as well as the clone $\mathrm{T}(28.56 \%$ rel.) reached values above the level of " $\mathrm{x}+\mathrm{s}$ " (28.41\% rel.). The range of the ratio of humulene in the tested clones corresponded to Saazer, Sládek, Kazbek, Rubín and Agnus.

\section{Selinene}

The average ratio of selinene was $2.33 \%$ under $81.67 \%$ variability, this value presented the highest content within all the essential oils. No clone showed the ratio of selinene under the level of "x-s" (0.43\% rel.). However, an extremely high ratio of selinene was recorded in DZ (8.95\%), which was even above the level of " $x+3 s$ " ( $8.05 \%$ rel.). The same ratio of selinene as DZ was found in Bohemie and Vital. The results revealed that DZ did not have features of Saaz hops.

\section{What did our results bring?}

We can conclude that only Osvald's clone no. 86 and the clone US did not exhibit any extreme values exceeding the limit levels in the contents and compositions of essential oils. They corresponded to the average of the tested set.

It is interesting that out of the cultivated Osvald's clones no. 31,72 and 114 certain clones show a higher or lower ratio of myrcene (Osvald's clone no. 31), caryophyllene (Osvald's clones no. 31 and 72) or farnesene (Osvald's clone no. 114). The differences may be caused only by a two-year assessment period because according to the already published information the average ratio of essential oils is in the given range. Nesvadba et al. (2013) stated that Osvald's clones no. 31, 72 and 114 had the ratio of myrcene between 25 and $40 \%$ rel., which does not correspond to the obtained results. The ratio of caryophyllene commonly moves between 6 and $9 \%$ rel., for farnesene it is $14-20 \%$ rel., for humulene $15-30 \%$ rel. and selinene $0.5-1.5 \%$ rel. and our declared values did not correspond to this.

\section{DNA analyses}

Genetic DNA analyses confirmed the results we obtained. Most of the studied hop genotypes are identical with "Žatecký poloraný červeňák" ("Saaz semi-early red bine hop", see figure 4). There was evidence that Saazer hop cuttings were spread through Europe (Germany, Poland, France) at the beginning of the $19^{\text {th }}$ century (Alberts, 2020). There was only one insignificant difference in allele ZPF8_356a (Figure 5), which divided Saazer hops into two groups. $\mathrm{HCH}$ and US were genetically identical but differ- 
Table 3 The composition of essential oils and their content in studied hop clones

\begin{tabular}{|c|c|c|c|c|c|c|}
\hline Clone & $\begin{array}{l}\text { Content } \\
(\% \mathrm{w} / \mathrm{w})\end{array}$ & $\begin{array}{l}\text { Myrcene } \\
\text { (\% rel.) }\end{array}$ & $\begin{array}{c}\text { Caryophyllene } \\
\text { (\% rel.) }\end{array}$ & $\begin{array}{l}\text { Farnesene } \\
\text { (\% rel.) }\end{array}$ & $\begin{array}{l}\text { Humulene } \\
\text { (\% rel.) }\end{array}$ & $\begin{array}{l}\text { Selinene } \\
\text { (\% rel.) }\end{array}$ \\
\hline Osvald's clone 31 & 0.59 & 20.01 & 7.99 & 17.49 & 21.94 & 1.35 \\
\hline Osvald's clone 72 & 0.49 & 15.12 & 8.76 & 15.67 & 22.75 & 1.67 \\
\hline Osvald's clone 86 & 0.60 & 16.53 & 9.96 & 20.14 & 21.81 & 1,68 \\
\hline Osvald's clone 114 & 0.56 & 14.51 & 10.66 & 21,40 & 20.91 & 1.72 \\
\hline Osvald's clone 124b & 0.53 & 16.33 & 14.73 & 11.21 & 32.13 & 2.76 \\
\hline Osvald's clone 126 & 0.65 & 17.55 & 14.32 & 12.43 & 28.38 & 2.44 \\
\hline Osvald's clone 136 b & 0.41 & 11.75 & 11.78 & 17.51 & 28.60 & 2.05 \\
\hline Osvald's clone 147 a/l & 0.77 & 23.14 & 8.89 & 19.72 & 17.89 & 1.48 \\
\hline M = Mastýřovický & 0.35 & 20.03 & 9.30 & 14.27 & 23.83 & 1.20 \\
\hline S = Staročeský & 0.45 & 14.67 & 10.74 & 23.81 & 22.12 & 1.62 \\
\hline $\mathrm{T}=$ Tršický & 0.31 & 10.53 & 12.99 & 15.30 & 28.56 & 3.12 \\
\hline ZP = Žatecká populace & 0.68 & 18.44 & 9.69 & 18.01 & 22.66 & 1.71 \\
\hline HCH = Hřebčí chmel & 0.35 & 14.87 & 11.29 & 18.65 & 24.97 & 1.67 \\
\hline US = Úštěcký smetaňák & 0.44 & 14.87 & 11.01 & 19.00 & 26.30 & 1.60 \\
\hline DZ = Dubský zeleňák & 0.37 & 13.14 & 15.85 & 4.35 & 26.90 & 8.95 \\
\hline$x$ & 0.50 & 16.10 & 11.19 & 16.59 & 24.65 & 2.33 \\
\hline s & 0.14 & 3.33 & 2.34 & 4.75 & 3.76 & 1.91 \\
\hline Vk & 27.04 & 20.70 & 20.94 & 28.61 & 15.27 & 81.67 \\
\hline$x-s$ & 0.37 & 12.77 & 8.85 & 11.85 & 20.88 & 0.43 \\
\hline$x+s$ & 0.64 & 19.43 & 13.54 & 21.34 & 28.41 & 4.24 \\
\hline$x-2 s$ & 0.23 & 9.43 & 6.51 & 7.10 & 17.12 & -1.48 \\
\hline$s+2 s$ & 0.77 & 2.76 & 15.88 & 26.09 & 32.18 & 6.14 \\
\hline
\end{tabular}

ent from Saazer hop. They seem to be very close to Saazer hop as its seedling with a wild male plant. DZ was also genetically different from Saazer hop. This genotype was selected near Dubá at the end of $18^{\text {th }}$ century. It was known for its higher yield and resistance to fungal disease, but its aroma quality was worse and rough. In spite of this quality, it was grown on one third of Czech hop acreage in 1846 (Vilikovský, 1936). It was fully replaced by Saazer hop at the beginning of the $20^{\text {th }}$ century. DZ is genetically identical with the old Russian variety of Serebrianka. It can be supposed that DZ had been transferred to Ukraine before this variety was selected in 1930s (Neve, 1991). Osvald's clone no. $124 \mathrm{~b}$ and 126 have been identical with the variety of Fuggle, which was discovered in Kent (England) by Richard Fuggle in 1861 (Neve, 1991). It can be supposed that Dr. Karel Osvald grew this variety in his experimental hop garden and used it for selections.

\section{Conclusion}

The presented study dealt with Czech historical hop clones that are saved in the Czech Republic's collection of genetic resources. In terms of the yield, the highest values were detected in $\mathrm{HCH}$, US and DZ. However, $\mathrm{HCH}$ and
US showed simultaneously a very low content of alpha acids $(1.05 \% \mathrm{w} / \mathrm{w})$, which is an insignificant value for brewing practice. Moreover, HCH and US are genetically identical with a wild male origin and they cannot be commonly grown in practice. In turn, the DZ clone rather differed in composition of essential oils from Saaz hops, which serve as a benchmark. This fact is related to a genetical difference of both plants. Even the M clone is not suitable for practice due to its very low yield.

Further Osvald's clone no. 136b showed a higher yield, however its alpha acids content was under $2 \%$, even though it had a high content of beta acids and DMX as well as an adequate composition of essential oils.

The other clones reached a similar yield to Saazer (Osvald's clones no. 31, 72 and 114). From these clones Osvald's clone no. $124 \mathrm{~b}$ together with the clones M, S and $\mathrm{T}$ exhibited lower contents of alpha acids.

A sufficient content of alpha acids was detected in Osvald's clone no. 126 as well as in ZP, even though Osvald's clone no. 126 showed a higher ratio of caryophyllene. The best parameters were identified in Osvald's clone no. $147 \mathrm{a} / \mathrm{I}$ with the yield of $0.84 \mathrm{t} / \mathrm{ha}$ and the highest content of alpha acids $(3.88 \% \mathrm{w} / \mathrm{w})$. Osvald's clone no. $124 \mathrm{~b}$ and 126 are selections within the variety of Fuggle. 
Figure 4 Dendrogram of genetic distances of 15 studied hop genotypes, 18 world old landrace cultivars and 21 Czech hop cultivars

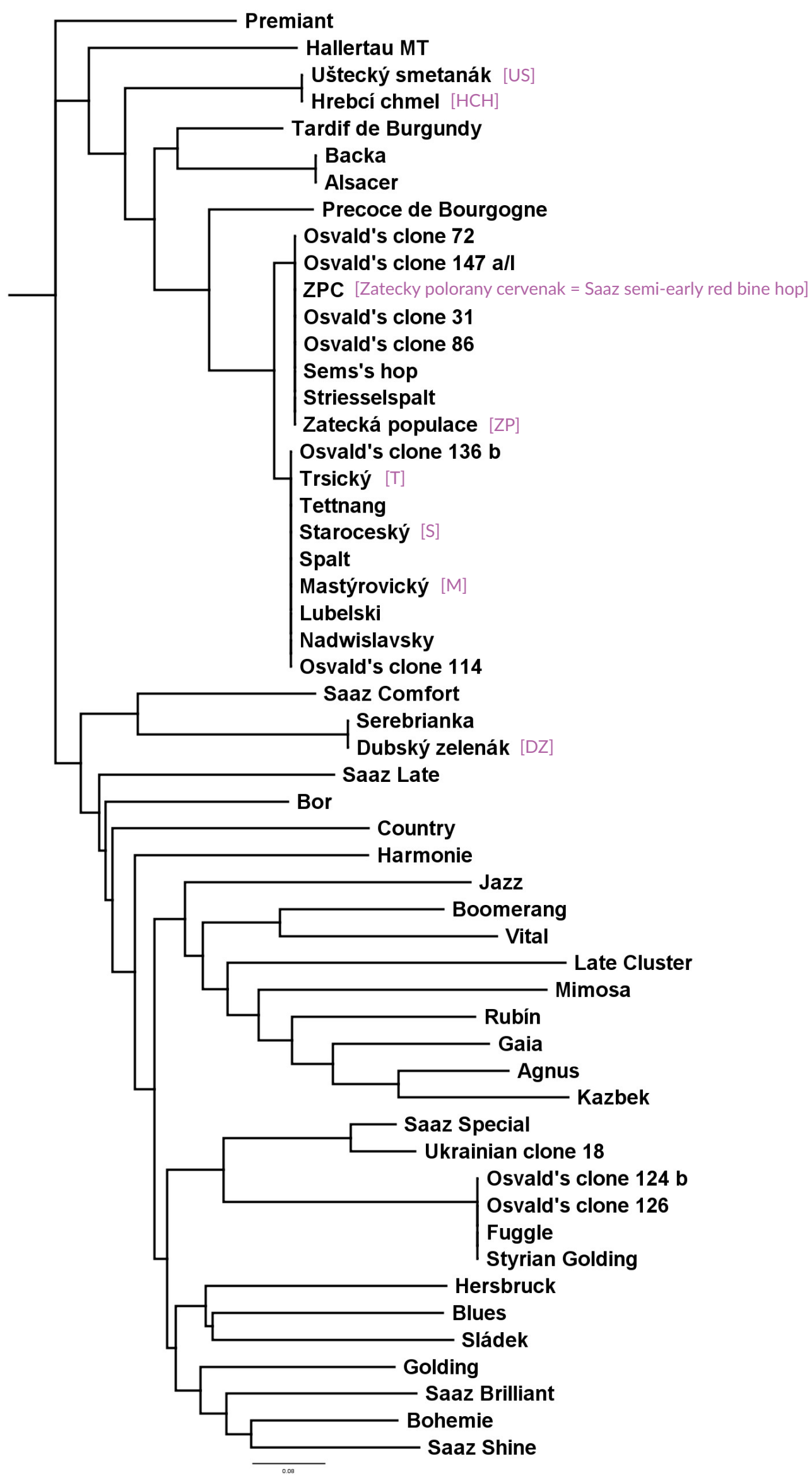


Figure 5 Capillary electrophoresis analyses of PCR products of ZPF8 microsatellite locus for samples: Osvald's clones no. 86, Mastýrovický (M), Osvald's clones no. 136b, Osvald's clones no. 147 a/l, Staročeský (S), Tršický (T) and Žatecká populace (ZP)
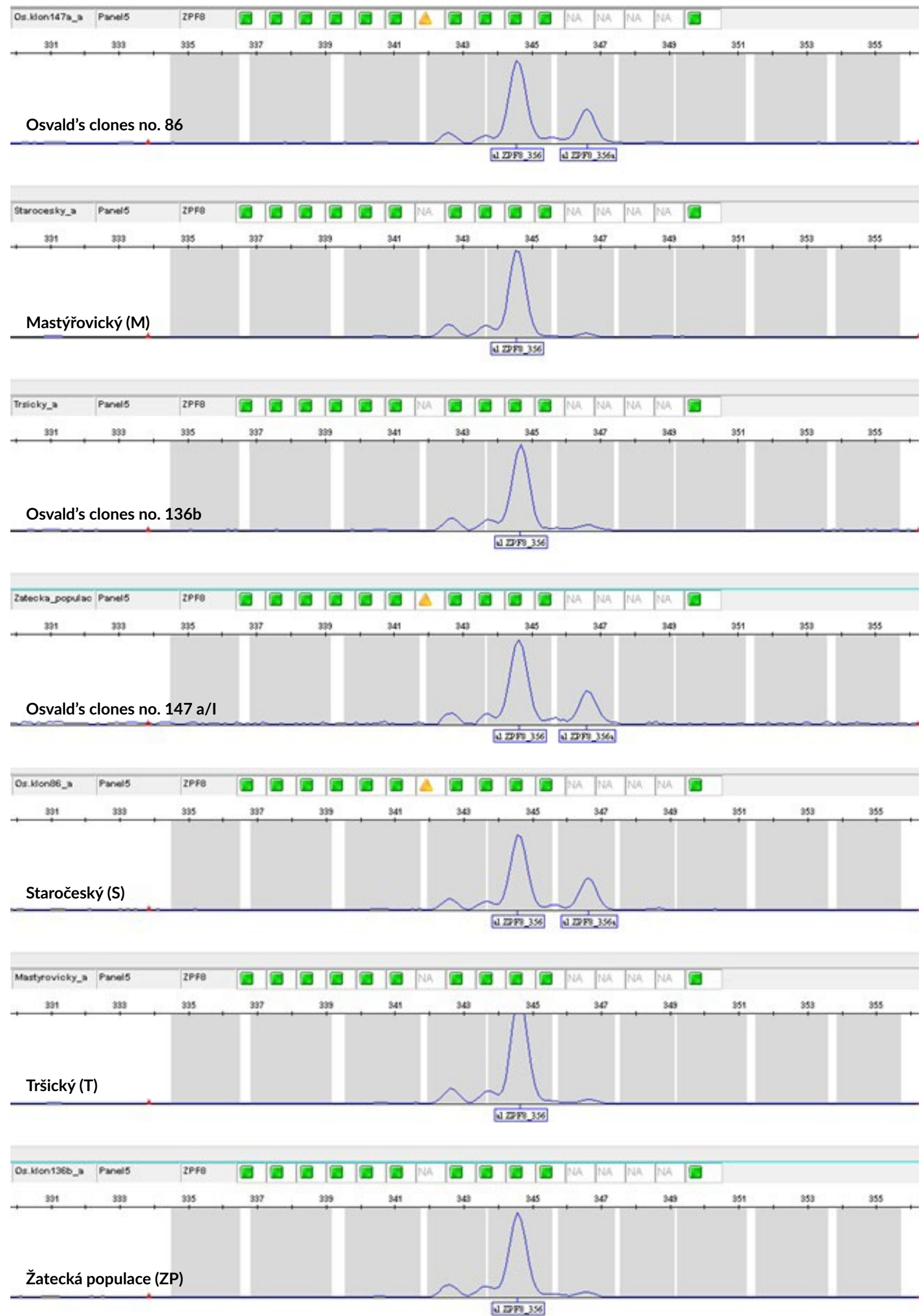
The results showed that many of the tested clones have good characteristics either from the view of yield or the content of hop resins. As it has already been mentioned, we have only research results from a period of two years and therefore we will continue in the work with historical hop clones from the individual hop growing regions in the future.

\section{Acknowledgement}

This work was supported by the Czech Ministry of Agriculture within the National Program of Conservation and Utilization of Genetic Resources in Plans and Biodiversity no. 51834/2017-MZE-17253/6.2.1.

\section{References}

Alberts, L. (2020). Žatec, cradle of Saaz hops and landmark of commercial hop cultivation. Brewery History, 181, 43-50.

Beránek, F. (1970). Dosavadní výsledky a perspektivy šlechtění žateckého chmele (eng. Current results and perspectives of breeding Saaz hop). Chmelařství, 43(6), 82-84. Available only in Czech.

Chodounský, F. (1900). Studie o chmeli (eng. Study on hop). České listy hospodářské, Praha. Available only in Czech.

Ježek, J., Klapal, I., Krofta, K., Nesvadba, V., Patzak, J., Pokorný, J., Svoboda, P., Veselý, F., Vostřel, J. (2015). Chmel 2015 - Př́ručka pro pěstitele chmele (eng. Hops 2015 - Handbook for hop growers). Hop Research Institute Co., Ltd., Žatec, 152 pp. ISBN 978-80-86836-98-0.

Krofta, K. (2008). Hodnocení kvality chmele: Metodika pro praxi 4/2008. (eng. Evaluation of hop quality: Methodology for practice 4/2008.) Hop Research Institute, Ltd., Žatec, 52 pp. ISBN 978-80-86836-843 Available in Czech from: https://invenio.nusl.cz/record/170477/ files/nusl-170477_1.pdf

Krofta, K., Klapal, I., Vojtěchová, D., Ondráček, J., Kroupa, F., Tichá, J. (2019). Hodnocení kvalitativních parametrů českých chmelů ze sklizně 2018 (eng. Evaluation of qualitative parametres of Czech hops from the harvest of 2018). Chmelařství, 92(1-2), 2-11. Available only in Czech

Krofta, K., Patzak, J., Nesvadba, V., Mikyška, A., Slabý, M., Čejka, P. (2013). Vital - The Czech hop Hybrid variety. Kvasný průmysl, 59(1), 13-17. https://doi.org/10.18832/kp2013001

Krofta, K., Vojtěchová, D., Tichá, J. (2020). Hodnocení kvalitativních parametrů českých chmelů ze sklizně 2019 (eng. Evaluation of qualitative parametres of Czech hops from the harvest of 2019). Chmelařství, 93(1-2), 7-15. Available only in Czech.

Linhart, J., Nesvadba, V. (1994). Odrůdová skladba českého chmele (eng. Varietal composition of Czech hops). Chmelařství, 67(6), 69-76. Available only in Czech.

Nesvadba V. (2008). Vývoj chmelových odrůd v České republice (eng. Development of ho varieties in the Czech Republic). Chmelařství 81(7-8), 93-96. Available only in Czech.
Nesvadba V., Krofta K. (2008). Variabilita obsahu pivovarsky a farmaceuticky významných látek u genofondu chmele (eng. Variability of the substance content important for brewing and pharmaceutical industry in the gene pool of hop). Sborník 5. vedeckej konferencie „Hodnotenie genetických zdrojov rastlín pre výživu a polnohospodárstvo“, 6.-7. mája 2008 Piešt’any, Slovensko. Available only in Czech.

Nesvadba, V. (2001). Dědičnost kvalitativních znaků chmele (eng. Inheritance of qualitative traits in hop). Thesis, Czech University of Life Science, Prague. Available only in Czech.

Nesvadba, V., Brynda, M., Henychová, A., Ježek, J., Kořen, J., Krofta, K., Malířová, I., Patzak, J., Polončíková, Z., Svoboda, P., Valeš, V., Vostřel, J. (2013). Development and tradition of Czech hop varieties. Hop Research Institute, CO., LTD., Žatec, 91 pp.

Nesvadba, V., Charvátová, J. (2020). Nové odrůdy chmele registrované v roce 2019 (eng. New hop varieties registered in 2019). Sborník přednášek a př́spěvků ze semináře Agrotechnika chmele konaného 20.2.2020, 163-171. ISBN 978-80-86836-40-9. Available only in Czech.

Nesvadba, V., Polončíková, Z., Henychová, A., Krofta, K., Patzak, J. (2012). Atlas českých odrůd chmele (eng. The Catalogue of Czech hop varieties). Chmelařský institut s.r.o. Žatec. ISBN 978-80-87357-11-8 Available from: http://invenio.nusl.cz/record/161364/files/nusl161364_1.pdf

Neve, R.A. (1991). Hops. Chapman and Hall, London, 266 pp. ISBN 0-41230330-2

Osvald, K. (1929). Kultura chmele po stránce šlechtitelské (eng. Hop culture in terms of breeding), Český chmelař. Věstník odb. Jednoty chmelařské Žatec, 9, 73-79 and 10, 84-86. Available only in Czech.

Osvald, K. (1931). Šlechtění chmele v Deštnici (trans. Hop breeding in Deštnice), Český chmelař, 4, 28-29. Available only in Czech.

Patzak, J., Krofta, K., Henychová, A. (2017). Metody a markery pro prokázání autenticity českých odrůd chmele (eng. Methods and markers for proving the authenticity of Czech hop varieties). Certifikovaná metodika, Žatec, Hop Research Institute, CO., LTD., Žatec, 86 pp. ISBN 978-80-86836-18-8. Available only in Czech.

Rígr, A., Beránek, F. (1991). Odrůdy českého chmele (eng. Varieties of Czech hops), Chmelařství, 64(1), 3-5. Available only in Czech.

Slabyhoudek, K. (1985). Nový klon chmele (eng. A new hop clone), Chmelařství, 58(2), 28. Available only in Czech.

Vent, L. (1999). Skupiny odrůd chmele a jejich využití v pivovarském průmyslu (eng. Groups of hop varieties and their use in the brewing industry), Chmelařství, 72(11), 173-175. Available only in Czech.

Vilikovský, V. (1936). Dějiny zemědělského průmyslu v Československu od nejstarších dob až do vypuknutí světové krise hospodářské (eng. History of the agricultural industry in Czechoslovakia from the earliest times until the outbreak of the world economic crisis). Ministerstvo zemědělství republiky Československé, Praha, 948 pp. Available only in Czech.

Zelenka, V., Rígr, A. (1983). Uplatnění výsledků šlechtění chmele (eng. Application of hop breeding results). Chmelařství, 56(9), 123-124. Available only in Czech. 